\title{
Developing a Framework of Improved Decision Usefulness in Financial Information
}

\section{Ibnu Qizam ${ }^{1}$ \\ Faculty of Economics and Business \\ UIN Syarif Hidayatullah Jakarta, Indonesia}

\begin{abstract}
Surel : qzami68@gmail.com
\section{ABSTRACT}

It is indispensable to improve decision usefulness for decisionmaking process for business. This study attempts to seek a framework of expanding a concept of decision usefulness (DU) through a regulatory-process check and a review of financial information literature and the extent to which future research opportunities could emerge from this DU concept for the improved decision usefulness (IDU). The regulatory process and research trends on financial information show that financialinformation decision has evolved from reliability-driven to relevance-driven financial-information theories and moves forward to international accounting standardization issues. To this end, the development of 'synthesis' theories and approaches in financial information offers many future empirical-study chances for improved decision usefulness.
\end{abstract}

$\begin{array}{llll}\text { Keywords: } & \begin{array}{l}\text { Decision Usefulness; } \\ \text { Reliability-Driven }\end{array} & \text { Financial } & \text { Information; } \\ & \begin{array}{l}\text { Relevance-Driven } \\ \text { International Accounting Standardization. }\end{array}\end{array}$

\section{Mengembangkan Kerangka Peningkatan Kegunaan Keputusan dalam Informasi Keuangan}

\begin{abstract}
ABSTRAK
Sangatlah penting untuk meningkatkan decision usefulness sejauhmana informasi keuangan berguna untuk pembuatan keputusan untuk proses pembuatan keputusan bisnis. Penelitian ini berusaha untuk mencari rerangka perluasan konsep decision usefulness (DU) melalui penyelidikan proses regulasi dan sintesis literatur informasi keuangan dan sejauh mana peluang penelitian masa depan yang dapat dimunculkan dari konsep DU ini dalam rangka perbaikan DU (improved decision usefulness atau IDU). Proses regulasi dan tren penelitian tentang informasi keuangan menunjukkan bahwa konsep DU atas informasi keuangan telah berkembang dari teori informasi keuangan yang (lebih) digerakkan oleh keandalan (reliability) menjadi teori informasi keuangan yang digerakkan oleh relevansi (relevance) dan bergerak menuju ke isu standardisasi akuntansi internasional. Sampai di sini, pengembangan teori dan pendekatan 'sintesis' terhadap informasi keuangan menawarkan banyak peluang studi empiris di masa depan untuk memperbaiki konsep DU.
\end{abstract}

Kata Kunci: $\quad$ Konsep Kebergunaan Keputusan; Informasi Keuangan; Informasi Keuangan yang Digerakkan oleh Keandalan; Informasi Keuangan yang Digerakkan oleh Relevansi; Standardisasi Akuntansi Internasional.

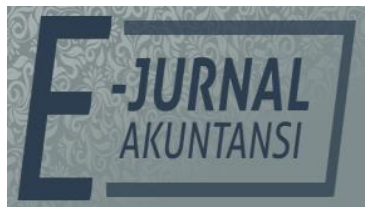

e-ISSN 2302-8556

Vol. 31 No. 5

Denpasar, Mei 2021

Hal. 1229-1246

DOI:

10.24843/EJA.2021.v31.i05.p12

PENGUTIPAN:

Qizam, I. (2021). Developing a Framework of Improved Decision Usefulness in

Financial Information. EJurnal Akuntansi, 31(5), 12291246

RIWAYAT ARTIKEL: Artikel Masuk: 23 Desember 2021 Artikel Diterima: 24 Mei 2021

Artikel dapat diakses : https://ojs.unud.ac.id/index.php/Akuntansi/index 


\section{INTRODUCTION}

This study is directed at seeking a framework of expanding a concept of decision usefulness (DU) through checking a regulatory process and applying a synthesis of financial information literature, and the extent to which future empirical-study chances could emerge from this DU concept for the improved decision usefulness.

Addressing the first issue, it is familiar to say that financial information quality is crucial in decision-making both by investors and by other users. Decision-making by investors and management cannot be set apart from financial information. Many researchers have provided evidence that the use of financial information will produce better and efficient decisions. Financial information and its characteristics have been abundantly researched up to now. Some of those discussions address the necessity to explore the qualitative features as delineated by the generally accepted accounting principles (GAAP), the International accounting standards board (IASB), and also the International financial reporting standards (IFRS). This, in turn, leads to how to operationalize the quality of financial reporting as real indicators of decision usefulness used by stakeholders to assess both the reliability and relevance of financial information.

Many researchers have pioneered empirical studies of accounting via various methods and procedures. Take, for example, Jones (1991) has initiated accrual models; Choi et al. (1997) have much-studied value-relevance models. Beretta and Bozzolan (2004) have scrutinized specific elements in annual reports, while Schipper and Vincent (2003) and Van-Beest et al. (2009) have also shed much light on qualitative-characteristic models.

The degree of decision usefulness reflecting the quality of financialstatement information sets can be measured through the attributes of both perspectives. Through the use of the attributes of both perspectives, the level of decision usefulness on the information set of the company's financial statements can be determined under either the information perspective or measurement perspective or the combination of both. Under an information perspective, attributes that indicate the level of decision-usefulness can be designated through the size of the CAR (cumulative abnormal returns), ERC (earning response coefficients), or variance between prices and intrinsic values (Kirschenheiter, 1997). The size of the information perspective attributes is certainly both crosssectionally and intertemporally different. The greater the market reaction (indicated by the magnitude of CAR or ERC) of a firm is, for example, the higher the information quality will be. Meanwhile, under a measurement perspective, referring to historical cost-based financial statements, the disclosure of unrecorded goodwill is both cross-sectionally and inter-temporally different. The lower the level of unrecorded goodwill shown by the higher covariance value between intrinsic value and price (Kirschenheiter, 1997) or the low level of goodwill denoted by the clean surplus model, or the high ratio between market value and total (book value) assets, the higher the information quality will be. Overall, financial information attributes which could originate from the two perspectives can be designated as the values of CARs, ERCs, the covariance of intrinsic value to market price, or other financial attributes as proxies reflecting 
information uncertainty, e.g., leverage ratio, book-to-market ratio, stock return volatility, and firm size (Zhang, 2006).

Unfortunately, these previous studies have never explored, to the best of the author's knowledge, a chronological review on a conceptual framework of developing decision usefulness through a look at historical regulations and accounting research literature. Most studies generally examine details of financial disclosure partially, but how the usage of financial information to increase decision usefulness is not reviewed through a clear understanding of the previous literature. Also, previous studies have not made an inference as to how the past regulations correspond to empirical accounting research.

Synthesis (content) analysis was conducted by historically examining financial information regulation and research trends. It was also applied to analyse such financial information issues and themes as clean surplus by Feltham and Ohlson (1995), efficient market hypothesis (EMH) by Fama (1968), disclosure theory (Botosan \& Plumlee, 2013; Dhaliwal et al., 1979). Through these procedures, this study is intended to develop a framework of improved decision usefulness concept which could be emitted from the trends of relevancereliability trade-off usage of financial information; how the financial information is chronologically evolving in reflecting decision usefulness issues; and what empirical research opportunities this framework could provide in the future for the improved decision usefulness.

To deal with this issue, the next discussion will consist of a research method, results and discussion, and conclusion.

\section{RESEARCH METHOD}

Some qualitative procedures, including content analysis and historical approach, were adopted in this study, such as data collection and reduction, descriptive analysis and data presentation, category selection, material evaluation, and conclusion (Sekaran \& Bougie, 2010).

In the first step, important words and concepts were selected as the keywords to explore some primary databases such as:

Table 1 . The primary databases

\begin{tabular}{lcc}
\hline No. & Name of Database & Links \\
\hline 1 & Springer & www.springerlink.com \\
2 & SAGE & https://journals.sagepub.com \\
3 & Wiley & www.wiley.com \\
4 & JSTOR & www.jstor.org \\
5 & Science-direct & https://www.sciencedirect.com \\
6 & Emerald Insight & www.emeraldinsight.com \\
7 & Researchgate & www.researchgate.net \\
8 & Taylor and Francis & https://taylorandfrancis.com \\
9 & SSRN & https://www.ssrn.com \\
10 & Cairn.info & https://www.cairn.info \\
\hline
\end{tabular}

Source: Research Data, 2020

The selected keywords encompassed, inter alia, "financial information" and "concepts and attributes of financial information" e.g., normative accounting research, positive accounting theory and research, relevance, reliability, qualitative characteristics, historical-cost accounting, current-value accounting, 
information perspective, and measurement perspective, "attributes of marketbased accounting and efficient market hypothesis" e.g., CAR (cumulative abnormal return), ERC (earnings-response coefficients), asymmetric information, accruals, decision usefulness, value-relevance, etc; institutions and rules related to accounting regulation processes such as CAP (committee of accounting procedure), IASB, FASB, IFRS, GAAP, and their sub-rules and sub-regulatory bodies were also explored from the extant literature.

Fifty-seven articles have been collected and categorized into some themes. The articles belonging to the theoretical reviews of financial information research (twenty-four articles) encompass groups of articles and their related themecategories: A1 (five articles), A2 (five articles), A3 (two articles), A4 (three articles), A5 (two articles), A6 (two articles), and A7 (five articles) (see Table 2).

Table 2. Theoretical Research Collection Of Financial Information

\begin{tabular}{|c|c|c|c|c|}
\hline No & $\begin{array}{l}\text { Theme } \\
\text { categories }\end{array}$ & Themes & $\begin{array}{l}\text { Number } \\
\text { of } \\
\text { articles }\end{array}$ & Researchers \\
\hline 1 & A1 & $\begin{array}{l}\text { Value-relevance literature- } \\
\text { evolution of US GAAP- } \\
\text { accounting standard } \\
\text { review-capital market } \\
\text { research review }\end{array}$ & 5 & $\begin{array}{l}\text { Dyckman and Zeff (1984), } \\
\text { Herath and Albarqi (2017); } \\
\text { Holthausen and Watts (2001); } \\
\text { Lev (1989), Zeff (2005) }\end{array}$ \\
\hline 2 & A2 & $\begin{array}{l}\text { Positive accounting } \\
\text { theory, clean surplus } \\
\text { theory, fundamental } \\
\text { analysis, budget control, } \\
\text { fundamental analysis }\end{array}$ & 5 & $\begin{array}{l}\text { Feltham and Ohlson (1995), } \\
\text { Lev and Thiagarajan (1993), } \\
\text { Staubus (1961), Stedry (1960), } \\
\text { Watts and Zimmerman } \\
\text { (1978) }\end{array}$ \\
\hline 3 & A3 & $\begin{array}{l}\text { Disclosure practices-reg } \\
\text { effect-analyst forecast } \\
\text { accuracy }\end{array}$ & 2 & $\begin{array}{l}\text { Ball (2016); Camfferman and } \\
\text { Zeff (2017) }\end{array}$ \\
\hline 4 & A4 & $\begin{array}{l}\text { Cap market equilibrium, } \\
\text { market imperfections, and } \\
\text { investment, EMH }\end{array}$ & 3 & $\begin{array}{l}\text { Fama (1970), Fama (1968), } \\
\text { Karuna (2019). }\end{array}$ \\
\hline 5 & A5 & $\begin{array}{l}\text { Cost-benefit of disclosure, } \\
\text { textual analysis of } \\
\text { corporate disclosure }\end{array}$ & 2 & $\begin{array}{l}\text { Elliott and Jacobson (1994), Li } \\
\text { (2010) }\end{array}$ \\
\hline 6 & A6 & $\begin{array}{l}\text { Risk-information, } \\
\text { information uncertainty, } \\
\text { and stock return }\end{array}$ & 2 & $\begin{array}{l}\text { Beretta and Bozzolan (2004); } \\
\text { Zhang (2006) }\end{array}$ \\
\hline $\begin{array}{c}7 \\
\text { Total }\end{array}$ & A7 & $\begin{array}{l}\text { Information quality, } \\
\text { decision-usefulness } \\
\text { criterion, earning quality, } \\
\text { balance-scorecard } \\
\text { performance }\end{array}$ & $\begin{array}{c}5 \\
24\end{array}$ & $\begin{array}{l}\text { Hepworth (1956), } \\
\text { Kirschenheiter (1997), } \\
\text { Laughlin and Puxty (1981), } \\
\text { Schindler (1958) }\end{array}$ \\
\hline
\end{tabular}

Source: Research Data, 2020

While the results of article grouping for theme categories concerning empirical market-based accounting research of financial information include thirty-three articles. 
Tabel 3. Empirical Research Collection Of Financial Information

\begin{tabular}{|c|c|c|c|c|}
\hline No & $\begin{array}{l}\text { Theme } \\
\text { categories }\end{array}$ & Themes & $\begin{array}{l}\text { Number } \\
\text { of } \\
\text { articles }\end{array}$ & Researchers \\
\hline 1 & B1 & $\begin{array}{l}\text { Stock-based } \\
\text { compensation }\end{array}$ & 2 & $\begin{array}{l}\text { Aboody et al. (2004a; } \\
\text { 2004b). }\end{array}$ \\
\hline 2 & B2 & Regulatory effect & 2 & $\begin{array}{l}\text { Ball et al. (2000), Benston } \\
\text { (1969). }\end{array}$ \\
\hline 3 & B3 & $\begin{array}{l}\text { value-relevance of } \\
\text { financial reporting and } \\
\text { information content } \\
\text { studies }\end{array}$ & 6 & $\begin{array}{l}\text { Ball and Brown (1968), } \\
\text { Baridwan et al. (2001), } \\
\text { Beaver (1968), Cormier et } \\
\text { al. (2000), Mirza et al. } \\
\text { (2018), Ohlson and } \\
\text { Juettner-Nauroth (2005). }\end{array}$ \\
\hline 4 & B4 & $\begin{array}{l}\text { risk-relevance and cost of } \\
\text { capital }\end{array}$ & 2 & $\begin{array}{l}\text { Beaver et al. (1970), Ou } \\
\text { (1990). }\end{array}$ \\
\hline 5 & B5 & $\begin{array}{l}\text { the economic value of } \\
\text { financial disclosure and } \\
\text { voluntary disclosure }\end{array}$ & 3 & $\begin{array}{l}\text { Botosan and Plumlee } \\
\text { (2013), Dhaliwal et al. } \\
\text { (1979), Lai et al. (2014). }\end{array}$ \\
\hline 6 & B6 & $\begin{array}{l}\text { Market prices-audit } \\
\text { opinion-auditor } \\
\text { behavior-audit strategy }\end{array}$ & 1 & Falk et al. (1999) \\
\hline 7 & B7 & $\begin{array}{l}\text { Earnings persistence- } \\
\text { stock returns; ERC }\end{array}$ & 2 & $\begin{array}{l}\text { Collins et al. (1994), } \\
\text { Kormendi and Lipe } \\
\text { (1987) }\end{array}$ \\
\hline 8 & B8 & Earnings management & 1 & Jones (1991) \\
\hline 9 & B9 & $\begin{array}{l}\text { Corporate performance- } \\
\text { IOS -investment decision }\end{array}$ & 1 & Farooq et al. (2015). \\
\hline 10 & B10 & $\begin{array}{l}\text { Stock prices-accrual-cash } \\
\text { flow-future earnings } \\
\text { (return prediction- } \\
\text { earnings prediction) }\end{array}$ & 3 & $\begin{array}{l}\text { Hájek and Olej (2013), } \\
\text { Holthausen and Larcker } \\
\text { (1992), Ou and Penman } \\
\text { (1989). }\end{array}$ \\
\hline 11 & B11 & $\begin{array}{l}\text { Corporate governance- } \\
\text { firm performance }\end{array}$ & 1 & Pillai et al. (2018). \\
\hline 12 & B12 & $\begin{array}{l}\text { Tax-planning and tax } \\
\text { reporting }\end{array}$ & 1 & Hodder et al. (2003) \\
\hline 13 & B13 & $\begin{array}{l}\text { Quality of financial } \\
\text { reporting and earnings }\end{array}$ & 1 & Van-Beest et al. (2009) \\
\hline 14 & B14 & $\begin{array}{l}\text { Conservatism- } \\
\text { asymmetric timeliness }\end{array}$ & 1 & Pope and Walker (1999) \\
\hline 15 & B15 & Free cash-flow & 1 & Richardson (2006) \\
\hline 16 & B16 & $\begin{array}{l}\text { Market prices-non } \\
\text { earning information-CEO } \\
\text { compensation }\end{array}$ & 2 & $\begin{array}{l}\text { Choi et al. (1997), } \\
\text { Craighead et al. (2004). }\end{array}$ \\
\hline 17 & B17 & $\begin{array}{l}\text { Normative costing, } \\
\text { miscellaneous }\end{array}$ & 3 & $\begin{array}{l}\text { Ashton (1974), Brummet } \\
\text { (1957), Ayturk et al. } \\
\text { (2017). }\end{array}$ \\
\hline Total & & & 33 & \\
\hline
\end{tabular}

Source: Research Data, 2020 
While the results of article grouping for theme categories concerning empirical market-based accounting research of financial information include thirty-three articles. B1 (two articles), B2 (two articles), B3 (six articles), B4 (two articles), B5 (three articles), B6 (one article), B7 (two articles), B8 (one article), B9 (one article), B10 (three articles), B11 (one article), B12 (one article), B13 (one article), B14 (one article), B15 (one article), B16 (two articles), and B17 (three articles) (See Table 3).

The next procedures such as re-arranging, re-categorizing, reducing, and analyzing were also conducted to reveal the specific themes from the extant literature of financial information, i.e., concerning how the chronological process of accounting regulation has happened; how the chronological process of accounting research literature is like; how decision usefulness concept is applied in financial information. The trajectory of decision usefulness for financial information, then, could be traced chronologically from pre-1930 to 2010spresent. The outcome of data rearrangement could be descriptively displayed to follow the chronological paths from two different poles: relevance-driven (in the upper area) and reliability-driven (in the bottom area). Through this data display, the events of financial information were chronologically plotted to swing between the two areas (relevance-driven and reliability-driven for financial information).

Through identifying how the regulation process and the empirical research have linked to each other, Figure 1 was provided to display events relevant to the 'tone' of decision-usefulness. As such, a synthesis could be made to develop the framework of an improved decision usefulness concept for future empirical accounting research opportunities (as seen in Figure 2).

\section{RESULTS AND DISCUSSION}

In the decade of 1930s and since the Market Crash 1929, applying historical cost accounting remains to be the concern by SEC to make financial information credible. SEC then established The Committee on Accounting Procedure (CAP) 1939 to issue many APB series (Accounting Research Bulletin). In the 1940s, under the influence of the monograph (An Introduction to Corporate Accounting Standards) written by Paton and Littleton, placing more emphasis on the principle of historical accounting cost, alternative accounting methods were first allowed. During the two decades of the 1930s and 1940s, much attention was paid to normative research, as seen in the Journal of Accountancy, The Accountants' Magazine, The Canadian Chartered Accountant, or The Australian Accountantapproximately more than $20 \%$ of which were focused on accounting education issues. In this regard, normative research usually includes two types: (1) prescription for policy, approximately between $20 \%$ and $54 \%$, and (2) development of an accounting framework from 1956 to 1959, where more or less between $6 \%$ and $17 \%$ were provided by the Accounting Review.

In the 1950s, big accounting firms showed different conclusions between uniformity vs. flexibility. APB then succeeded the committee on accounting procedure (CAP) in 1959. The objective of APB is to synchronize the differences in accounting practices. It was during this period research got much interest to narrow the gap between philosophical accounting concepts and practices. During 
this decade, while normative study still existed, accounting research in this period much adopted recently interdisciplinary approach (from finance, psychology, statistics, and operation research), accounting education, and a seemingly increased number of empirical accounting research which began to rise. The portion looks still stagnant at approximately $5 \%$ while the accounting education seems to be the most prominent, i.e., at a range of $20 \%-32 \%$ while the rest points to a lower portion. Besides, many Ph.D. dissertations also more reflected normative issues, inter alia, by Hepworth (1956), Brummet (1957), Schindler (1958), and so on. Only Paton Jr. (1958) addressed a view empirical accounting issues, i.e., price-level accounting.

In the 1960s, the debate between historical cost versus current values arose due to the increased current issues of accounting research. Some 1930s-scholars from accounting education consistently did not agree with the ideas of historical cost accounting, while some 1960s-scholars were in more consent with current value accounting. The 1960s was the period of awakening where the Journal of Accounting Research founded in 1963 was first published, then followed by the other journals, such as Abacus, Journal of Accounting Education and Research in 1965. Inspired by these journals, many influential accounting works evidently appeared, i.e., inter alia, Stedry (1960), Chambers (1961), Staubus (1961), and many others. In 1965 and 1966, AAA published two books, Studies in Accounting Research and A Statement of Basic Accounting Theory that began to be interested to the use of 'the usefulness' approach in building accounting theory. Besides, the most important milestone boosting empirical accounting research on decision usefulness of financial information was inspired by Ball and Brown (1968) with his phenomenal methodology of an event study. Dyckman and Zeff (1984) consider this decade more productive and more directive in the accounting research literature than any previous decade.

Only two years from 1959, the portion of accounting education, which was published, dropped significantly. In 1966, AAA's new book, entitled A Statement of Basic Accounting Theory, was launched to change normative accounting ideas into a 'decision usefulness' concept of accounting. More accounting empirical issues were more widespread due to the fund from the Ford Foundation (19531964) and the usage of other interdisciplinary fields, such as mathematics, statistics, and social science, while the US securities markets were also increasingly competitive and domestically or internationally complex. The performance of the Accounting Principles Board (APB) was then under the SEC's criticism.

In the 1970s, the accounting firms have lost confidence in the APB attributable to its underperformance, and two study groups were formed, i.e., Wheat Study Group (concerned with accounting-principle development) and the Trueblood Study Group (more focused on the financial-statement objectives). Through a recommendation by the two groups, an independent, full-time, and formal institution was founded, that is the Financial Accounting Standard Board (FASB) (coming into operations on July 1, 1973) in addition to IASC (International Accounting Standards Committee) which was also formed two days before. FASB was considered more professional with its endorsement of current values principles relative to historical cost accounting. The term 'decision 
usefulness' was firstly introduced by the Trueblood Study Group in developing accounting standards, and become the core subject of the new FASB. Between 1974-1985), FASB has successfully developed two necessary conceptual frameworks (objectives of financial reporting by business enterprises in 1978 and qualitative characteristics of accounting information in 1980), and many series of SFAS (statement of financial accounting standards). The period of 1968-1970 was regarded as a turning-point with much empirical accounting research, more emphasizing empirical research and mathematical modeling rather than normative research, especially since the phenomenal findings from Ball and Brown (1968) and Fama et al. (1969) (in The Journal of Accounting Research, for example, there was a big increase from only 9 articles in 1963-1967 to 25 articles in 1968-1970 and the presence of the positive accounting theory (PAT) by Watts and Zimmerman (1978). This implies that accounting numbers lead to improved decision usefulness.

In the 1980s, the flexibility of FASB in setting standards was bothered with the industry's interventions to accommodate its interest regarding the measurement of earnings and also a cash-flow statement. Concerning research trends, since the finding of Ball and Brown (1968), the next research findings to link capital market to accounting numbers (the decision usefulness) and also the empirical tests of EMH (efficient market hypothesis) progressively emerged with a variety of improved measurement: CARs (Cumulative Abnormal Returns) from Ball and Brown (1968), ERCs (Earning Response Coefficients) by Kormendi and Lipe (1987), and PAT by Watts and Zimmerman (1978)'s a great impact on much accounting research of accounting in many modes. This is the decade when financial information is much researched through an information-perspective-ondecision-usefulness approach (see Scott, 2000).

In the 1990s, FASB began moving on current-value standard issues (e.g., SFAS 106, SFAS 115, SFAS 123, and SFAS 133). The value relevance of financial information got much interest from the FASB, directed to improve the informativeness of financial information (together with EMH testing). Despite the increased value relevance, only a small proportion of return variability is attributable to earnings (about 2-5\%), implying that the less quality of historicalcost-accounting information (see Collins et al., 1994). This condition raised the need for non-earnings information (Ou \& Penman, 1989; Lev \& Thiagarajan, 1993; Holthausen \& Larcker, 1992) and the current value measurements (being more swung to follow measurement perspective regime). To respond to this, newly specific methodological issues such as accounting conservatism (Pope and Walker (1999) and clean-surplus theory (Feltham \& Ohlson, 1995) appeared. Overall, the discussion of accounting research was more swung to follow the measurement perspective regime more adhered to fair-value accounting than information perspective one (the improved decision usefulness).

In the 2000s, FASB launched SFAS 141, SFAS 142, and other regulations, an exposure draft to converge with IFRS 2 on share-based payment issued by IASB (International Accounting Standard Board) as a successor of IASC in 2001 (efforts have been conducted since the 1990s). IASB is also required by The SarbanesOxley Act of 2002 to be more independent and put more emphasis on 'principlesbased standards', rather than length and detail. Both the FASB and the IASB 
moved very quickly to boost the progress to achieve convergence by 2008 . By 2009, IFRS has been adopted by the European Union, and, then, followed by the other countries, including the attempts to converge U.S. GAAP and international standards until the end of 2008. At that time, a roadmap for adopting international standards was issued by SEC.

Two paths of empirical accounting research were highlighted during this decade: the first is concerned with the more widespread use of non-earnings measures of accounting to test information content and value-relevance of accounting information with new methodological issues and other contexts such as performance evaluation, compensation (Aboody et al., 2004a; Craighead et al., 2004); accounting information and tax (Hodder et al., 2003); financial disclosure, and economic consequence (Botosan \& Plumlee, 2013); the second refers to the apparent attempts to move forward to international financial reporting standard (IFRS). Since the IASB, global accounting issues could be well dealt with. There was a tremendous amount of accounting literature on IFRS and its impact as seen, among other things, in Cormier et al. (2000), Pope and Walker (1999), and many others.

In the 2010s-present, convergence and global accounting standards were pushed by the SEC. As such, FASB worked hard in support of convergence for U.S. GAAP and IFRS. The final report regarding 'the work plan for consideration of incorporating international financial reporting standards into the financial reporting system for the US issuers' was published by SEC in 2012. The 2012 final report described the findings concerning some significant issues supporting the strong attempts of incorporating IFRS into the U.S. financial reporting system. Unfortunately, a recommendation has not yet been successfully launched to the US Commission, and the attempts of harmonization between U.S. GAAP and IFRS still went on.

Facilitated with advanced digital technology, big data, and also industry 4.0, the current issues from the previous decade, such as advanced accounting measurement about capital market either from a methodological or a conceptualinquiry point of view has been progressively evolving, including the movement to adopt IFRS for convergence, e.g., between US-GAAP and IFRS, and its research implication. Take, for example, new modes of auditing strategy to deal with 'modern' accounting frauds, using RAM (real activity manipulation) rather than conventional accruals (see also Hartono and Saputro, 2019). Besides, as identified by Hartono and Saputro (2019), soft information has a significant impact on present accounting research in many areas, e.g., tone (Hájek \& Olej, 2013); readership of financial information (Loughran and McDonald, 2014). A broader context of the society in macro-economic analysis and of real behavioral effects for investors, managers, and other stakeholders as part of the whole system constituting eco-system of life and environment were also recommended to be involved in developing accounting practices and its relevant accountingresearch issues by applying a multi-disciplinary approach.

Given the above discussion, it concludes that the term 'decision usefulness' is first introduced by a group called 'the Trueblood Study Group,' established by the AICPA (1971) amid the succession period of APB by the FASB in 1973

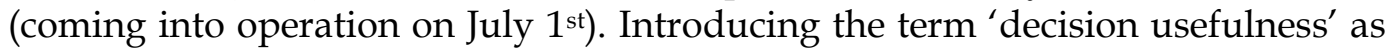


an approach in the development of accounting standards was initiated by Trueblood Study Group, i.e., when a booklet about 'Objectives of Financial Statements' was launched by Trueblood Study Group. This then leads to a milestone of many various attempts to set a conceptual framework of financial reporting (Zeff, 2005)

Through FASB, many works of financial reporting concepts have been successfully produced, especially between 1974-1985 when a concept statement for part one (concerning objectives of financial reporting by business enterprises) was announced in 1978, and a concept statement for part two (regarding qualitative characteristics of accounting information) released in 1980; to step onward, many series of SFAS (Statement of Financial Accounting Standards) are established. Since then, many countries follow this concept with their various country-specific contexts. In essence, financial information has now been more standardized with a sound conceptual framework (Zeff, 2005).

Based on a sounder financial standard, financial information, as it is known, is made mandatory for firms because its existence is indispensably recognized as a basis for business decision-making. Moreover, after the occurrence of many crises involving the credibility of financial information both directly and indirectly, there are also increased demands for the extent and quality of financial disclosures. Long before FASB was established in 1973, APB (issuing many series of ARBs, i.e., Accounting Research Bulletins) to succeed CAP (Committee on Accounting Procedure) appeared in 1959; APB was requested to set accounting standards as a result of reducing the gap between accounting concepts and practices through research. Hence, it was a time when Americans firmly hold the belief in research. The study was believed to be able to overcome the differences among philosophical concepts, accounting practices, and opinions coming from leaders of the accounting profession.

Ball and Brown (1968) was, then followed by other researchers, e.g., Beaver (1968), Benston (1969), Ou and Penman (1989), Ou (1990), and so on. Upon the importance of earnings in financial information, the researchers then develop information content of earnings more precisely, moving on to the range, i.e., why the market responds to the firms' earning or loss differently. This difference in response is then better known as ERCs (earning-response coefficient), as a form to develop other decision usefulness measurements of accounting information for investors (Kormendi \& Lipe, 1987). The above description is designated as a decision usefulness concept under an information perspective.

Decisions usefulness concept of accounting information, then, continues to grow, and to step to a different point of view, i.e., a measurement perspective concept of decision usefulness, which, nowadays, is also increasingly growing, i.e., efforts to increase the value-relevance of accounting information while keeping it reliable. Approaches to measuring decision usefulness not only use the proxies of contemporary assumptions between earnings (changes in earnings) and price (changes in securities prices) but also emphasize the relationship between 'fundamental signals' of accounting information and the value of future earnings or future earnings predictions (Ou, 1990; Ou \& Penman, 1989). 


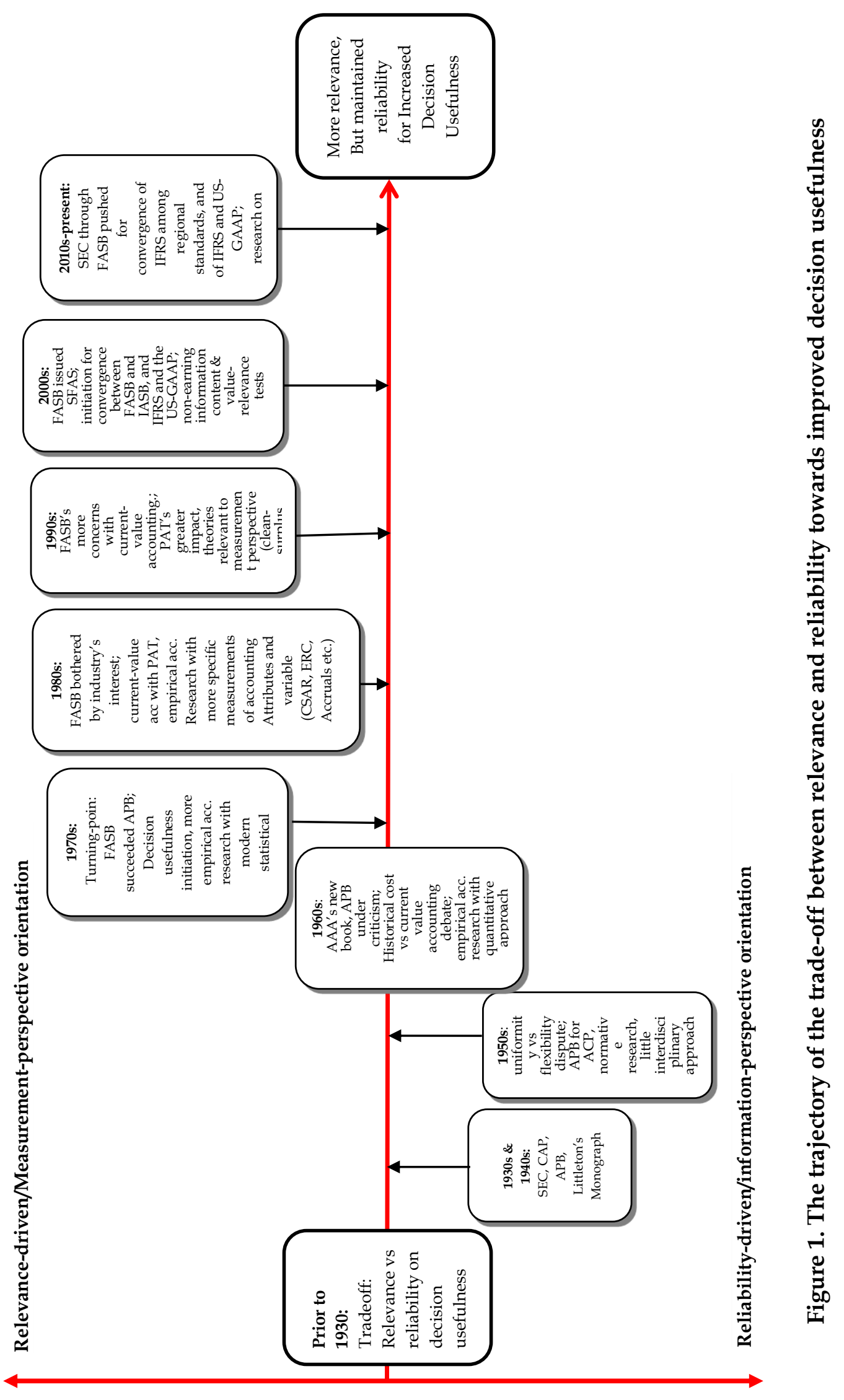


From a theoretical perspective, the development of measurement perspectives is strongly supported by both the theory of clean surplus (Feltham \& Ohlson, 1995), and disclosure theory (Botosan \& Plumlee, 2013; Dhaliwal et al., 1979). Under the clean surplus theory, an increase of a firm's value in the measurement perspective can be translated into a relation between asset's value and the fundamental signal of accounting information, which consists of two components: book value (bv) and goodwill (g).

Given Figure 1, the issues of decision usefulness of financial information move to follow the trade-off between a reliability-driven pole and a relevancedriven one. In a reliability-driven pole, decision usefulness of accounting information more emanates from historical cost accounting, placing more emphasis on reliability arguments in the decades of the 1930s, 1940s, 1950s, and, then, gradually rising to current-value accounting (relevance-driven pole) in the 1960s. Meanwhile, in a relevance-driven pole, decision usefulness of accounting information inspired by current-value accounting was observed to move from the 1960s to 1970s, 1980s, 1990s, 2000s, and 2010s, and the following years onwards were led to international standardization for convergence while keeping on more relevance but not leaving out reliability for decision usefulness.

Many opportunities for empirical accounting research will be very open for scholars and academics. These empirical research issues may move from the first angle of existing financial information, and other information items are treated as additional information. For the second angle, the research issues are directed to adopt the financial, starting from, inter alia, the problems of (international) standardization and integrated reports blended with the current issues of the financial information studies (e.g., investment-decision making, governance, and firms' performance; value-relevance and risk-relevance; auditing models and strategies; management and control; regulatory impacts; integrated reports and [international] standardization).

The following examples may relate to investment-decision making and firms' performance, e.g., Lai et al. (2014) who have explored how financial and other financial disclosure and corporate governance affect efficient investment. Meanwhile, Pillai et al. (2018) has also examined how financial and other financial disclosure and corporate governance have an impact on firms' performance.

The next issue could relate to value-relevance and risk-relevance. There appeared to be current research on applying integrated reports. The findings show that there exists to be a decreased information asymmetry, the increased quality of earnings report, and value-relevance of book value (Vena et al., 2019; Baboukardos \& Rimmel, 2016). They found that the increased quality of integrated reporting led to the improved financial-information value-relevance covering either equity or earning book values (Baboukardos \& Rimmel, 2016; Obeng et al., 2020) (see Figure 2).

\section{CONCLUSION}

Given the insights regarding the importance to utilize financial information from either academics or practitioners upon their examination through a great deal of research (from normative to positive and from reliability-driven to relevance- 
driven for financial information), discussion, and standard-setting process (from CAP to FASB and IFRS for financial information, this proposed framework of improved decision usefulness has been developed from identifying the patterns and nature emitted from a significant number of previous research literature.

Looking into the way the empirical research literature of financial has chronologically passed, many findings have contributed to standard-setting and business decision-making practices (decision usefulness). Through the dynamics of discussion and standard-setting process, developing decision usefulness for the financial information has evolved from reliability-driven and information perspective regime to relevance-driven and measurement perspective regime, from local or regional to international standard (IFRS) for convergence, and from the decade of 1930s after the Market crash 1929 which places more emphasis on historical cost accounting by CAP to the presence of FASB, IASB, US-GAAP, and IFRS which are more concerned with current-value accounting.

Adopting the concept of improved decision usefulness will be beneficial for many future empirical research opportunities. These empirical accounting issues may move from the angle of existing reliability-driven research of financial information, and other relevance-driven research of financial information are treated as additional discussion. As such, research issues may be the same as the current existing accounting research such as investment-decision making, governance and firms' performance; value-relevance and risk-relevance; auditing models and strategies; management, and control; regulatory impacts, and integrated reports and [international] standardization; and many others.

The other research issues may simultaneously adopt reliability-driven and relevance-driven research of financial information. Take, for instance, from the issues of standardization and integrated reports, and henceforth, the same issues as the financial information addresses (e.g., value-relevance, management and control, regulatory impacts, economic consequences, and methodological modes).

The users of information, including creditors and investors, encounter the trade-offs between relevance and reliability in financial reporting. To increase decision usefulness (henceforth, improved decision usefulness [IDU]), the reliability-driven financial disclosure quality is, in fact, synergistically accompanied by relevance-driven financial disclosure quality where the current trends move to put more emphasis on relevance-driven financial information quality blended with the International standardization issues. 


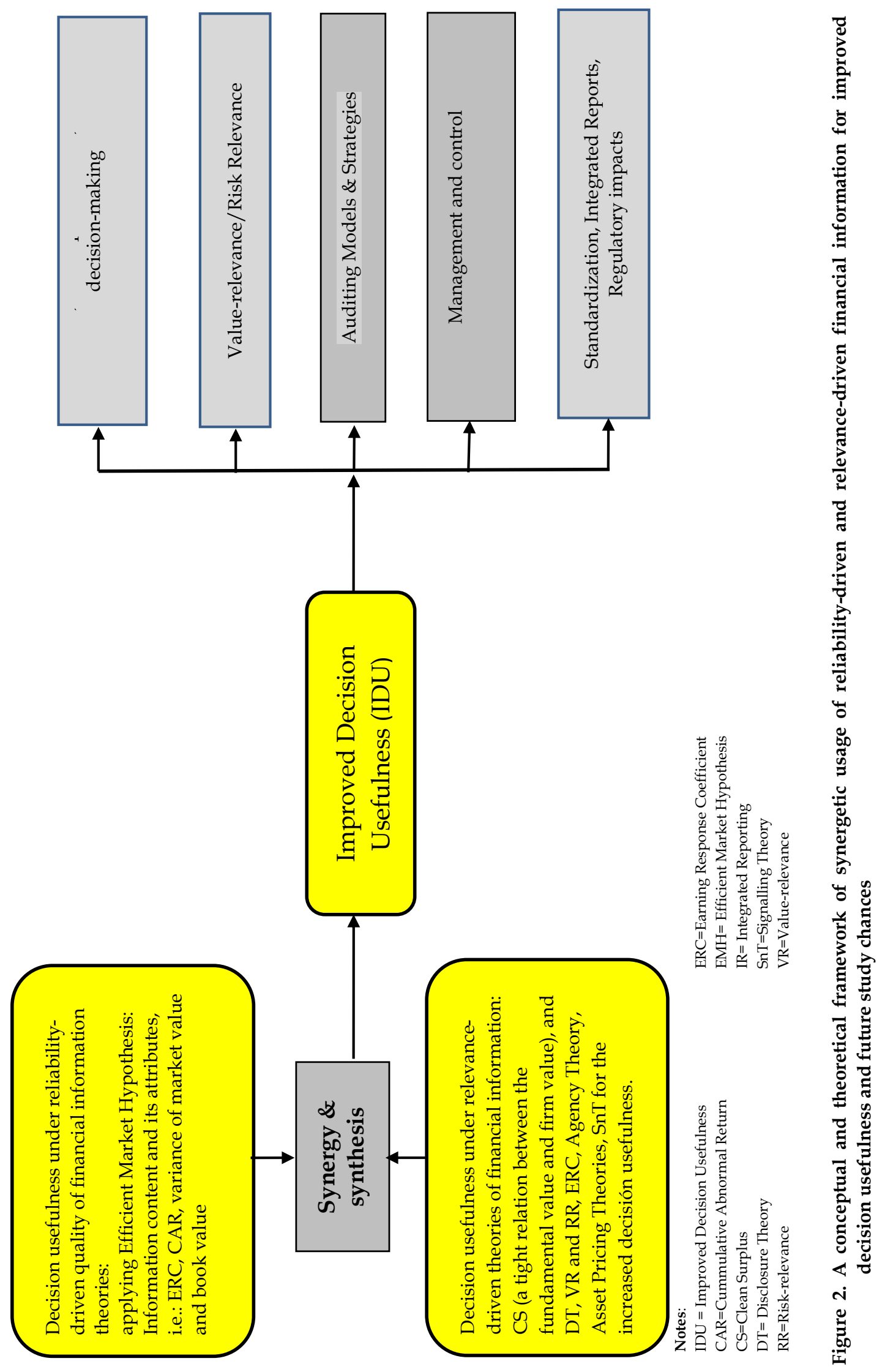




\section{REFERENCES}

Aboody, D., Barth, M. E., \& Kasznik, R. (2004b). SFAS No. 123 Stock-based compensation expense and equity market values. The Accounting Review, 79(2), 251-276. https://www.jstor.org/stable/3203244

Aboody, D., Barth, M., \& Kasznik, R. (2004a). Firms' voluntary recognition of stock-based compensation expense. Journal of Accounting Research, 42(2), 123-158. https:/ / doi.org/10.1111/j.1475-679X.2004.00132.x

Ashton, R. (1974). An experimental study of internal control judgments. Journal of Accounting Research, 12(1), 143-157. https://doi.org/DOI: 10.2307/2490532

Ayturk, Y., Asutay, M., \& Aksak, E. (2017). What explains corporate sukuk primary market spreads? Research in International Business and Finance, 40(April), 141-149. http://dx.doi.org/10.1016/j.ribaf.2017.01.002

Baboukardos, D., \& Rimmel, G. (2016). Value relevance of accounting information under an integrated reporting approach: A research note. Journal of Accounting and Public Policy, 35(4), 437-452. https:// doi.org/10.1016/j.jaccpubpol.2016.04.004

Ball, R. (2016). IFRS - 10 years later. Accounting and Business Research, 46(5), 545571. https://doi.org/doi:10.1080/00014788.2016.1182710

Ball, R., \& Brown, P. (1968). An empirical evaluation of accounting income numbers. Journal of Accounting Research, 6(2), 159-178. https:/ / doi.org/DOI: 10.2307/2490232

Baridwan, Z., Machfoedz, M., \& Tearney, M. G. (2001). An Evaluation of Disclosure Finacial Information by Public Companies in Indonesia.

Beaver, W.H., Kettler, P., \& Scholes, M. (1970). The Association between Market Determined and Accounting Determined Risk Measures. Accounting Review, 45(4), 654-682. https://www.jstor.org/stable/244204

Beaver, William H. (1968). The information content of annual earnings announcements. Journal of Accounting Research, 6(Empirical Research in Accounting: Selected Studies), 67-92. https://doi.org/DOI: $10.2307 / 2490070$

Beretta, S., \& Bozzolan, S. (2004). A framework for the analysis of firm risk communication. The International Journal of Accounting, 39(3), 265-288. https:// doi.org/10.1016/j.intacc.2004.06.006

Botosan, C.A., \& Plumlee, M. A. (2013). Are information attributes are priced? Business Finance and Accounting, 40(9-10), 21-53. https://doi.org/10.1111/jbfa.12044

Brummet, R. (1957). Overhead Costing. Ann Arbor: Bureau of Business Research, University of Michigan.

Camfferman, K., \& Zeff, S. A. (2017). The Challenge of Setting Standards for a Worldwide Constituency: Research Implications from the IASB's Early History. European Accounting Review, 27(2), 289-312. https:/ / doi.org/doi:10.1080/09638180.2017.1296780

Chambers, R. J. (1961). Towards A General Theory of Accounting. The University of Adelaide: Australian Society of Accountants Research Lecture.

Choi, B., Collins, D. W., \& Johnson, W. B. (1997). Valuation implications of reliability differences: The case of non-pension postretirement obligations. Accounting Review, 72(3), 351-383. https://www.jstor.org/stable/248476 
Collins, D. W., Kothari, S. P., Shanken, J., \& Sloan, R. G. (1994). Lack of timeliness and noise as explanations for the low contemporaneuos return-earnings association. Journal of Accounting and Economics, 18(3), 289-324. https://doi.org/doi:10.1016/0165-4101(94)90024-8

Cormier, D., Magnan, M., \& Morard, B. (2000). The contractual and value relevance of reported earnings in a dividend-focused environment. European Accounting Review, 9(3), 387-417. https:/ / doi.org/doi:10.1080/09638180020017131

Craighead, J., Magnan, M., \& Thorne, L. (2004). The impact of mandated disclosure on performance-based CEO compensation. Contemporary Accounting Research, 21(2), 369-398. https://doi.org/10.1506/BPCX-D3FCY8VY-M541

Dhaliwal, Dan S., Spicer, B. H., \& Vickrey, D. (1979). The quality of disclosure and the cost of capital. Journal of Business Finance and Accounting, 6(2), 245266. https:// doi.org/10.1111/j.1468-5957.1979.tb01089.x

Dyckman, T. R., \& Zeff, S. A. (1984). Two Decades of the Journal of Accounting Research. Journal of Accounting Research, 22(1), 225-297. https://doi.org/10.2307/2490710

Elliott, R. K., \& Jacobson, P. D. (1994). Costs and benefits of business information disclosure. Accounting Horizons, 8(4), 80-96.

Falk, H., Lynn, B., Mestelman, S., \& Shehata., M. (1999). Auditor independence, self-interested behavior and ethics: Some experimental evidence. Journal of Accounting and Public Policy, 18(4-5), 395-428. https://doi.org/10.1016/S0278-4254(99)00012-5

Fama, E. (1968). Risk, return and equilibrium: Some clarifying comments. The Journal of Finance, 23(1), 29-40. https://doi.org/10.1111/j.15406261.1968.tb02996.x

Fama, E. (1970). Efficient Capital Markets: A Review of Theory and Empirical Work. Journal of Finance, 25(2), 383-417, 25(2), 383-417. https:// doi.org/DOI: 10.2307/2325486

Farooq, S., Ahmed, S., \& Saleem, K. (2015). Overinvestment, growth opportunities and firm performance: Evidence from Singapore stock market. Corporate Ownership \& Control, 12(3), 454-467. https://doi.org/DOI: 10.22495/cocv12i3c4p6

Feltham, J., \& Ohlson, J. A. (1995). Valuation and clean surplus accounting for operating and financial activities. Contemporary Accounting Research, 11(2), 689-731. https://doi.org/10.1111/j.1911-3846.1995.tb00462.x

Hájek, P., \& Olej, V. (2013). Evaluating sentiment in annual reports for financial distress prediction using neural networks and support vector machines. In Engineering Applications of Neural Networks. EANN 2013. Communications in Computer and Information Science (Iliadis L., Papadopoulos H., Jayne C., Vol. 384). Springer, Berlin, Heidelberg. DOI https://doi.org/10.1007/978-3-64241016-1_1

Hartono, J., \& Saputro, J. A. (2019). Topik-topik Riset Akuntansi Pasar Modal (Market-based accounting research topics). In Kajian Literatur dan Arah Topik Riset ke Depan (Literature Review and Future Direction for Research Topics) (Prof. Jogiyanto Hartono M., MBA., Ph.D). Master-of-Science and 
Doctoral Program of Faculty of Economics and Business, Gadjah Mada University, Yogyakarta, Indonesia.

Hepworth, S. (1956). Reporting foreign operations. Ann Arbor: Bureau of Business Research. University of Michigan.

Hodder, L., McNally, M. L., \& Weaver, C. (2003). The Influence of Tax and NonTax Factors on Banks' Choice of Organizational Form. The Accounting Review, 78(1), 297-326. https://doi.org/DOI: 10.2308/accr.2003.78.1.297

Holthausen, R. W., \& Larcker, D. F. (1992). The prediction of stock returns using financial statement information. Journal of Accounting and Economics, 15(2), 373-411. https://doi.org/10.1016/0165-4101(92)90025-W

Jones, J.J. (1991). Earnings management during import relief investigations. Journal of Accounting Research, 29(2), 193-228. https://doi.org/DOI: $10.2307 / 2491047$

Karuna, C. (2019). Capital markets research in accounting: Lessons learnt and future implications. Pacific-Basin Finance Journal, 55(March), 161-168. https:// doi.org/10.1016/j.pacfin.2019.03.001

Kormendi, R., \& Lipe, R. (1987). Earnings innovations, earnings persistence, and stock returns. The Journal of Business, 60(3), 323-345. https://www.jstor.org/stable/2352874

Lai, S. M., Liu, C. L., \& Wang, T. (2014). Increased disclosure and investment efficiency. Asia-Pacific Journal of Accounting \& Economics, 21(3), 308-327, 21(3), 308-327. https://doi.org/DOI: 10.1080/16081625.2012.741791

Lev, B. (1989). On the usefulness of earnings: Lesson and directions from two decades of empirical research. Journal of Accounting Research, 27(Supplement), 153-192. https:/ / doi.org/DOI: 10.2307/2491070

Lev, B., \& Thiagarajan, S. R. (1993). Fundamental information analysis. Journal of Accounting Research, 31(2), 190-215. https:/ / doi.org/DOI: 10.2307/2491270

Loughran, T., \& McDonald, B. (2014). Measuring Readability in Financial Disclosures. Journal of Finance, 69(4), 1643-1671. https:/ /EconPavpers.repec.org/RePEc:bla:jfinan:v:69:y:2014:i:4:p:1643-1671

Obeng, V. A., Ahmed, K., \& Miglani, S. (2020). Integrated reporting and earnings quality: The moderating effect of agency costs. Pacific-Basin Finance Journal, 60(April), 101285. https://doi.org/10.1016/j.pacfin.2020.101285

$\mathrm{Ou}, \mathrm{J} . \mathrm{A} .(1990)$. The Incremental information content of non-earnings accounting numbers as earnings predictors. Journal of Accounting Research, 28(1), 144163. https:/ / doi.org/DOI: $10.2307 / 2491220$

Ou, Jane A., \& Penman, S. H. (1989). Financial statement analysis and the prediction of stock returns. Journal of Accounting and Economics, 11(4), 295329. https:/ / doi.org/10.1016/0165-4101(89)90017-7

Paton, W. J. R. (1958). A study in liquidity. Ann Arbor: Bureau of Business Research, University of Michigan.

Pillai, R., Al-Malkawi, \& Nizar, H. A. (2018). On the relationship between corporate governance and firm performance: Evidence from GCC countries. Research in International Business and Finance, 44(April), 394-410. http://dx.doi.org/10.1016/j.ribaf.2017.07.110 
Pope, P. F., \& Walker, M. (1999). International differences in the timeliness, conservatism, and classification of earnings. Journal of Accounting Research, 37(Supplement), 53-87. https:/ / doi.org/DOI: 10.2307/2491345

Schindler, J. (1958). Quasi-Reorganization. Ann Arbor: Bureau of Business Research, University of Michigan.

Scott, William R. (2000). Financial Accounting Theory (2nd Ed.). Prentice Hall.

Sekaran, U., \& Bougie, R. (2010). Research methods for business: A skill-building approach (Fifth Ed.). Haddington: John Wiley \& Sons.

Staubus, G. A. (1961). Theory of Accounting to Investors. Berkeley: University of California Press.

Stedry, A. (1960). Budget control and cost behavior. Englewood Cliffs, N.J.: PrenticeHall.

Van-Beest, Braam, G., \& Boelens, S. (2009). Quality of financial reporting: Measuring qualitative characteristics [Working Paper 09-108].

Vena, L., Sciascia, S., \& Cortesi, A. (2019). Integrated reporting and cost of capital: The moderating role of cultural dimensions. Journal of International Financial Management \& Accounting. https://doi.org/doi:10.1111/jifm.12113

Watts, R., \& Zimmerman, J. (1978). Towards a positive theory of the determination of accounting standards. The Accounting Review, 53(1), 112134. https://www.jstor.org/stable/245729

Zeff, S. A. (2005). The evolution of U.S. GAAP: The political forces behind professional standards. The CPA Journal, 75(1-2), 19-27. http://archives.cpajournal.com/2005/205/infocus/p18.htm

Zhang, X. F. (2006). Information Uncertainty and Stock Returns. The Journal of Finance, 61(1), 105-137. https:// doi.org/10.1111/j.1540-6261.2006.00831.x 